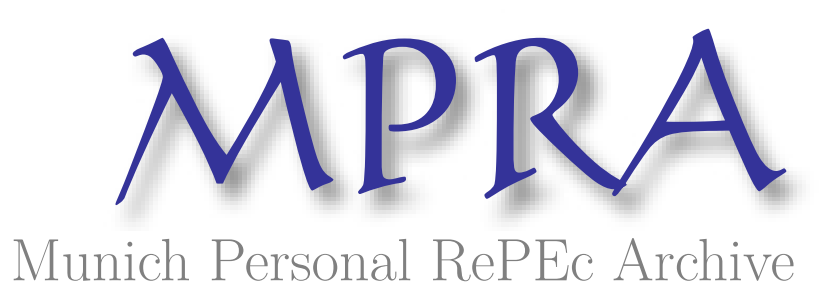

Agri-food impacts of Fukushima nuclear accident - lessons learned 10 years after disaster

Bachev, Hrabrin
Institute of Agricultural Economics, Sofia

May 2021

Online at https://mpra.ub.uni-muenchen.de/108041/

MPRA Paper No. 108041, posted 31 May 2021 08:56 UTC 


\title{
Agri-food Impacts of Fukushima Nuclear Accident - Lessons Learned 10 Years after Disaster
}

\author{
Hrabrin Bachev, Institute of Agricultural Economics, Sofia, hbachev@yahoo.com
}

\begin{abstract}
On March 11, 2011, the strongest ever recorded in Japan earthquake occurred which triggered a powerful tsunami and caused a nuclear accident in Fukushima nuclear plant. The latter was a "manmade" disaster having immense impacts on people's life, health, and property, infrastructure, supply chains, economy, policies, natural and institutional environment, etc. This paper presents work in progress and assesses preparedness for and agri-food impacts of the Fukushima nuclear disaster, identifies challenges in post-disaster recovery, and withdraws lessons for improving disaster risk management. Japan was not well prepared for such a huge disaster while the agri-food sector and consumption have been among the worst-hit areas. The triple disaster was a rare but high-impact event, therefore, it is necessary to "prepare for the unexpected". Risk assessment is to include diverse hazards and multiple effects of a likely disaster, it is to be discussed with all stakeholders, and measures taken to educate and train all for complex disasters. It is necessary to modernize property rights, regulations, safety standards, and norms, enhance the capability of responsible public authorities and improve coordination between diverse actors. It is important to set up mechanisms for effective public resource allocation and reduction of agents' costs. Different elements of the agri-food chain have dissimilar capabilities requiring differential public support. There is a strong "regional" interdependency of agrarian, food, and rural assets (and damages), and it is important to properly locate risk and take prevention and recovery measures. Disaster response demonstrated the important role of small-scale farms and food organizations, and the high efficiency of private, market, and collective governance. Before, during, and after a disaster, all available information from all sources is to be immediately publicized in understandable form through all possible means. Disaster provides an opportunity to discuss, introduce and implement fundamental changes in agricultural, economic, regional, energy, disaster management, etc. policies. It is important to learn from past experiences, prepare for multiple disasters, and make sure that "lessons learned" are not forgotten.
\end{abstract}

\section{Introduction}

On March 11, 2011, the most powerful earthquake ever recorded in Japan (magnitude of $9 \mathrm{Mw}$ ) occurred known as the Great East Japan Earthquake (GEJE). It triggered powerful tsunamis which caused a nuclear accident in one of the world's biggest nuclear power stations - the Fukushima Daiichi Nuclear Power Plant (FDNPP). Radioactive contamination spread through air, rains, dust, water circulations, wildlife, garbage disposals, transportation, and affected soils, waters, plants, animals, infrastructure, and population. Japanese agriculture, food industry, and agri-food consumption have been among the worst affected areas from the Fukushima Nuclear Accident (FNA) (Bachev and Ito, 2014, 2018; Bachev, 2019; FAO/IAEA, 2018; Hamada and Ogino, 2012; JFC, 2011-2014; Johnson, 2011; Koyama, 2013; Kunii et al., 2018; Monma et al., 2015; Nakanishi and Tanoi, 2013; Nakanishi, 2018; Oka, 2012; Sekizawa, 2013; Todo et al., 2015; Takebayashi et al., 2020; Ujiie, 2012; Watanabe, 2013). This paper presents the current results of a long-term on-going study and assesses preparedness for and long-term agri-food impacts of FNA, identifies challenges in post-disaster recovery, and withdraws lessons for improving disaster risk management. A multidisciplinary approach is applied and diverse types of monitoring, statistical, experts, stakeholder interviews, research, etc. data are used in the analysis. 


\section{Assessment of Preparedness and Agri-food Impacts}

The Agri-food sector of Japan was not well prepared for such a big disaster and badly affected by FNA (Bachev, 2014, 2019; Bachev and Ito, 2018). Adverse long-term effects on agriculture, food industries, and food consumption are in the following areas:

First, enormous production and income reduction due to radiation contamination, mandatory and voluntary shipment restrictions, increased inputs, production and marketing costs, costs of adaptation and implementation of new safety standards, diminished market demands and prices of agri-food products, etc. (Table 1). Initially, almost $55 \%$ of all farms were affected negatively by GEJE as in the worst-hit (Fukushima, Iwate, and Miyagi) prefectures $90 \%$ of holdings suffered mostly due to "prices decline" and "harmful rumours" (JFC, 2013). Damages to agriculture have been particularly big in areas around the nuclear plant, where farming and related activity is suspended or reduced affecting $8 \%$ of farmers and $9 \%$ of farmlands of Fukushima prefecture. Effective recovery in mostly impacted prefectures has been deterred by FNA impact, unavailable land and equipment, undecided settlement place, funding problems, etc. as the importance of FNA as a factor for "not resuming farming" increased (MAFF, 2019). Almost 60\% of food companies ( $82 \%$ in most affected regions, 94\% in Fukushima prefecture) were also severely affected by FNA due to cancelled orders, reduced sales and prices, increased input supply costs, etc. (JFC, 2014).

Second, there was radioactive contamination of farmlands, agrarian physical and biological assets, and infrastructure from FNA's fallout. Radioactive caesium contaminated $8 \%$ of the lands of Japan, $40 \%$ with radiation exceeding allowable level (MECSST, 2011). Heavily contaminated farmlands are located in 8 prefectures where radiation contamination ranges from $16-56600 \mathrm{~Bq} / \mathrm{kg}$ (MAFF, 2013). There have been huge public and private costs for cleaning farmlands and agrarian assets. Up-to-date $94 \%$ of farmland has recovered as well as $97 \%$ of fishery processing facilities have reopened (MAFF, 2021). Nevertheless, in 12 most accident-affected municipalities restoration of farming has been progressing slowly while some heavily contaminated areas require long-time before farming could resume. The agri-food sector is a major employer in affected regions, and after FNA thousands of farms' livelihood and businesses are destructed as a result of loss of lives, injuries, displacement, damages on property, infrastructure, community, and business relations. Much of the long-term damages from FNA on farmers' livelihood and possessions, physical and mental health, environment, lost community relations, etc. can hardly be evaluated in quantitative terms (Bachev and Ito, 2014, 2018).

Third, up to FNA there was no adequate system for agri-food radiation regulation and food safety inspection in Japan. Provisional regulatory limits for radionuclides in agri-food products were introduced after FNA which were upgraded to the world's strictest in 2012. Widespread inspections on radiation contamination have been introduced, and numerous production, shipment, and consumption restrictions on agri-food products imposed. Regular radiation tests have been carried on numerous agri-food products in 17 prefectures, including all rice bags and beef meat in Fukushima prefecture. There have emerged many private and collective inspection systems introduced by farmers, rural associations, food processors, retailers, local authorities, consumer organizations, independent agents, etc. some of which employing stricter than official safety norms. There are several products from contaminated areas of 17 prefectures, still subject to shipment restrains (outside Fukushima mostly covering mushrooms, wild plants, fish). Consequently, the number of agri-food items with the level exceeding safety standards diminished to zero in recent years all groups but mushrooms, wild plants, fishery products, wild bird, and animal meat (MAFF, 2020). Modernization of the food safety system has taken time and is associated with enormous public and private concerns, debates, and costs. 
Table 1. Agricultural Long-term Impacts and Major Challenges of Fukushima Nuclear Disaster

\begin{tabular}{|c|c|c|}
\hline Related to & Impacts & Challenges \\
\hline $\begin{array}{l}\text { Farmers } \\
\text { Agribusiness } \\
\text { managers } \\
\text { Hired Labour }\end{array}$ & $\begin{array}{l}\text { Physical and physiological } \\
\text { destruction } \\
\text { Evacuation }\end{array}$ & $\begin{array}{l}\text { Support system and consultation for } \\
\text { evacuees } \\
\text { Creation of infrastructure and } \\
\text { environment for people to return and stop } \\
\text { leaving } \\
\text { Shortage of farm managers and labour }\end{array}$ \\
\hline Lands and assets & $\begin{array}{l}\text { Contamination } \\
\text { Destruction }\end{array}$ & $\begin{array}{l}\text { Cleaning remaining farmlands } \\
\text { Inspecting and reinforcing agricultural } \\
\text { facilities }\end{array}$ \\
\hline Production & $\begin{array}{l}\text { Reduction or suspension of } \\
\text { activities }\end{array}$ & $\begin{array}{l}\text { Full scale recovery and revitalisation } \\
\text { Multiple risks management preparation } \\
\text { Enrolling in the agricultural insurance } \\
\text { Complying with hygiene and safety } \\
\text { standards }\end{array}$ \\
\hline $\begin{array}{l}\text { Distribution and } \\
\text { marketing }\end{array}$ & $\begin{array}{l}\text { Destruction } \\
\text { Shipment bans and } \\
\text { restrictions } \\
\text { New marketing channels }\end{array}$ & $\begin{array}{l}\text { Dispelling current and emerging rumours to } \\
\text { revive agriculture, food processing, } \\
\text { fisheries and rural tourism } \\
\text { Promotion of Fukushima products }\end{array}$ \\
\hline Economy & $\begin{array}{l}\text { Increased costs } \\
\text { Lost income } \\
\text { Lost employment } \\
\text { Lost capital value }\end{array}$ & $\begin{array}{l}\text { Sustainable public support } \\
\text { Modernisation } \\
\text { New income opportunities in affected } \\
\text { regions }\end{array}$ \\
\hline Food regulation & $\begin{array}{l}\text { Modernisation } \\
\text { standards, rules and } \\
\text { institutions }\end{array}$ & $\begin{array}{l}\text { Trust } \\
\text { Effective enforcement }\end{array}$ \\
\hline Food inspection & $\begin{array}{l}\text { Modernisation of } \\
\text { organisation and methods } \\
\text { Huge costs } \\
\text { Private and third party } \\
\text { modes }\end{array}$ & $\begin{array}{l}\text { Keep and improve monitoring system } \\
\text { Build trust } \\
\text { Recover private and collective costs }\end{array}$ \\
\hline $\begin{array}{l}\text { Organisation and risk } \\
\text { management }\end{array}$ & $\begin{array}{l}\text { Innovations } \\
\text { Private, collective, and } \\
\text { hybrid modes } \\
\text { Food chain management } \\
\text { Land consolidation }\end{array}$ & $\begin{array}{l}\text { Educating, training, informing, preserving } \\
\text { Future of traditional farming } \\
\text { Decentralisation of risk management }\end{array}$ \\
\hline Information & $\begin{array}{l}\text { Increasing } \\
\text { Diversification } \\
\text { Reliability }\end{array}$ & $\begin{array}{l}\text { Trust } \\
\text { Enormous costs }\end{array}$ \\
\hline Natural environment & $\begin{array}{l}\text { Long-term contamination } \\
\text { Destruction of biodiversity } \\
\text { and ecosystems }\end{array}$ & $\begin{array}{l}\text { Recover damages to wildlife, soils and } \\
\text { natural ecosystems } \\
\text { Safe transportation of contaminated soil to } \\
\text { Interim Storage Facility } \\
\text { Final disposal site for contaminated waste } \\
\text { Decontamination of Difficult to-return Zone }\end{array}$ \\
\hline $\begin{array}{l}\text { Research, } \\
\text { technological and } \\
\text { product innovations }\end{array}$ & $\begin{array}{l}\text { Huge dynamics of activity } \\
\text { and forms } \\
\text { New perspective areas }\end{array}$ & $\begin{array}{l}\text { Costs, efficiency, priorities } \\
\text { Destructed international cooperation due to } \\
\text { Corona crises }\end{array}$ \\
\hline $\begin{array}{l}\text { Agri-food } \\
\text { consumption }\end{array}$ & $\begin{array}{l}\text { Increased health concern, } \\
\text { checks, and oversupply } \\
\text { Secure procurement } \\
\text { modes }\end{array}$ & $\begin{array}{l}\text { An effective system for informing } \\
\text { consumers } \\
\text { Consumption of domestic and local agri- } \\
\text { food products }\end{array}$ \\
\hline Policies & $\begin{array}{l}\text { Increased public support } \\
\text { Shifting priorities } \\
\text { Modernisation of Food } \\
\text { Security, Energy, Health } \\
\text { care, Environmental etc. } \\
\text { policies } \\
\text { Ongoing debates }\end{array}$ & $\begin{array}{l}\text { Involving all stakeholders } \\
\text { Building disaster-resilient communities and } \\
\text { supply chains } \\
\text { Increasing domestically and local agri-food } \\
\text { consumption } \\
\text { Agri-food export promotion }\end{array}$ \\
\hline
\end{tabular}


Fourth, immediately after FNA there was the destruction of supply of potable water, foods, and necessities in most affected regions. Unprecedented for modern Japan food shortages occurred in disaster areas and big cities but food supply was quickly restored and important infrastructure rebuilt. There have been numerous restrictions on production, sales, shipments, and consumption of agri-food products in affected regions which stopped, delayed, or reduced effective supply of a range of products. Due to genuine or perceived health risk many wholesale traders, processors, and consumers stop buying agri-food products originated from "Northern Honshu", even in cases when it had been proven that food is safe (MAFF, 2020). "Reputation damage" is particularly important for many traditional products like rice, fruits, vegetables, mushrooms, milk, butter, beef, etc. which demand and prices significantly declined (Figure 1). Demands and prices for Fukushima agri-food products have been recovering but many consumers continue to select the region buying "rarely" or "not at all" from affected regions because they "worry about safety" (JFC, 2014; Takebayashi et al., 2020). Numerous consumers continue to disbelieve inspection systems and employ other ways to procure safe food through direct sales, contracts, origins, own or co-production, imports, etc.

Figure 1. Evolution of Total Agricultural Output, and Prices of Rice and Peaches in Fukushima Prefecture and Japan $(2010=100)$

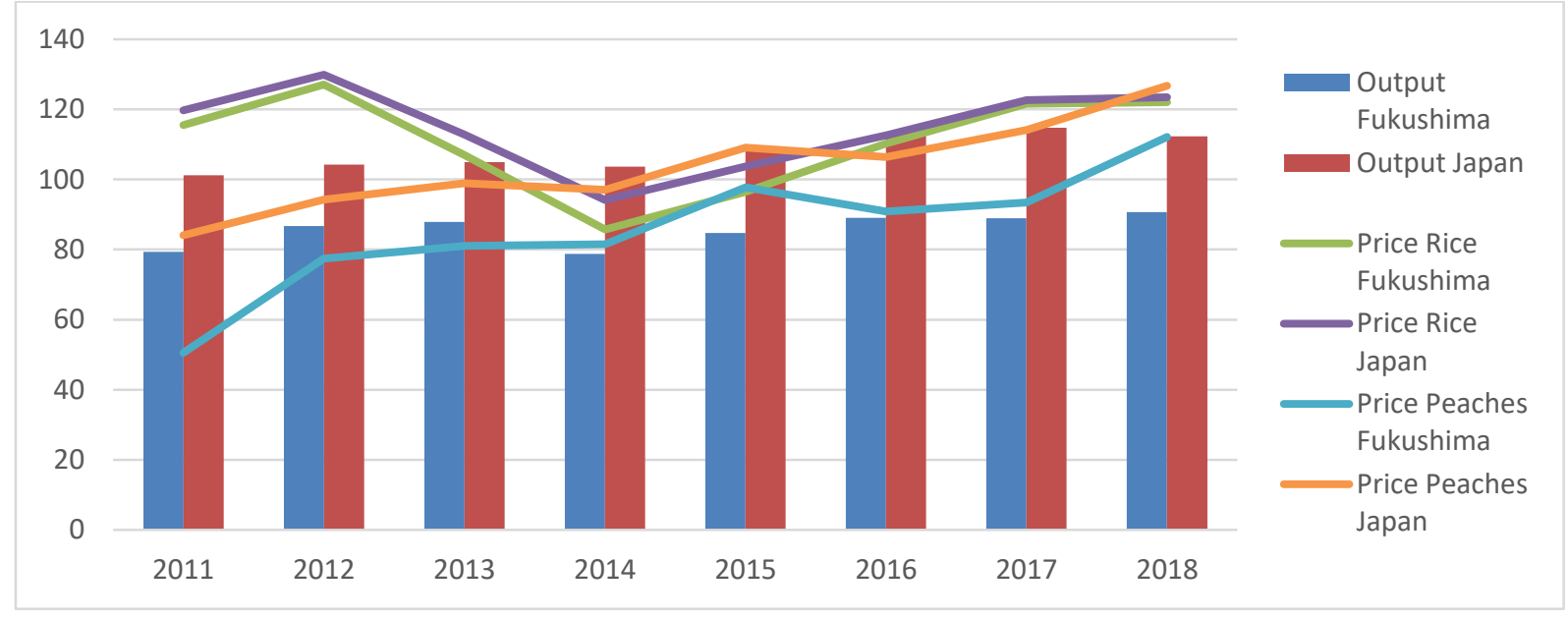

Source: Fukushima Prefectural Government, MAFF, 2021.

Fifth, FNA adversely affected international trade as 54 countries and regions imposed restrictions on agri-food imports from Japan, including major importers such as China, USA, Indonesia, Malaysia, South Korea, etc. As a result of strict inspection measures, promotion of a third-party GAP certification, information sharing, etc. many countries have eased or eliminated import restrictions but still, Fukushima products are not fully included (MAFF, 2021).

Sixth, FNA has positive effects on the agri-food sector in non-contaminated regions in which prices, demands, production, and sales opportunities have increased. Recovery from GEJE has been also associated with the consolidation of farmlands in reconstructed areas as well as the emergence of new (community, private, market, collective, hybrid, food chain, etc.) organizational and risk management modes. Besides, there has been a boom in technological, product, and organizational innovations in agrarian and other sectors, and enormous growth of new sectors (radiation testing, decontamination, energy saving, renewable energy, nuclear safety, debris cleaning, processing and disposal, research and development, robotics, ITC, no-soil and solar sharing farming, smart agriculture, branding, etc.) with huge investments of leading players, central and local governments, and numerous newcomers, joint ventures, etc. All they created new employment and income opportunities in affected regions and Japan. 
Our survey has found out that major factors for long-term persistence of FNA negative impacts on agriculture are: consumers' unwillingness to buy, long-time required for deactivating radiation, insufficient support from central government, produce low prices, low confidence in official information, lack of information, bad reputation, and little preparedness of public authorities (Bachev and Ito, 2018). The most important factors for food industries are lack of information, consumers' unwillingness to buy, long-time required for deactivating radiation, little preparedness of public authorities, bad reputation, insufficient support from central government, and low confidence in official information. The most important factors for food consumption are lack of information, low confidence in official information, insufficient support from the central government, and a bad reputation.

\section{$3 \quad$ Persisting Disaster Recovery Challenges}

After FNA a large-scale evacuation affecting 470000 people or $9 \%$ of the Fukushima prefecture population and $12 \%$ of prefecture territory was carried. Evacuation areas and the number of evacuees gradually have decreased (Map 1). Nevertheless "evacuation designated zones" still cover $365 \mathrm{~km} 2$ (2,4\% of Fukushima prefecture territory) while 41000 Fukushima residents continue to live as evacuees ( $75 \%$ in other prefectures), including 2000 in temporary housing (RA, 2021).

Map 2. Evaluation zones in Japan (past and 2021)
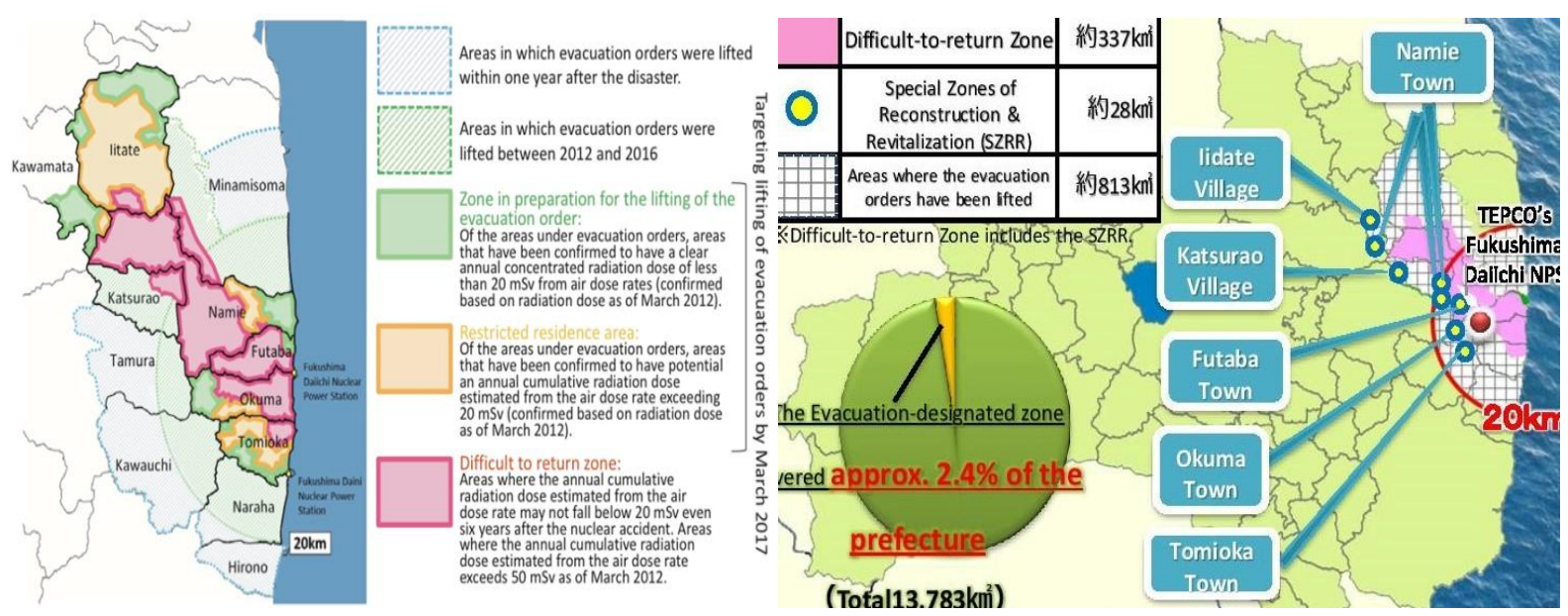

Source: Fukushima Prefectural Government

Evacuation and reconstruction is associated with number of challenges: failure for timely evacuation from certain highly contaminated areas, slow response of authorities, lack of sufficient public information in first stages of disaster, mistrust to public and private institutions, multiple displacements of many evacuees, divided communities and families, bad communication between different organizations, lack of financial resources, insufficient manpower and building materials, ineffective use of public funds, discrimination toward some evacuees, emotional conflicts between evacuees (about "self-evacuation", compensations, rebuilding modes), insufficient and unequal compensation, unequal decontamination and recovery of individual sectors (fast of construction industry, slow for farming, services, food processing, fishery) and regions (much slower for Fukushima), workers moving away from agri-food sector, unequal payment for work in traditional industries and government's emergency programs, substandard labour conditions for decontamination workers, increased individual and organized crimes, population decline (out-migration), long-time to obtain consent for reconstruction plans, difficulties of land acquisition for building cities, spikes in construction material prices, manpower shortages, lack of contractors, numerous lawsuits against TEPCO and authorities, delay in establishing Reconstruction Agency for coordinating multiple recovery efforts, unclear government guidelines for nuclear disaster recovery, revisions in national energy, disaster prevention etc. policies, lack of detailed contamination map for all agricultural lands, improper use of 
extension officers (obtaining samples while suppressing consulting, introducing technology, education), etc. (Bachev and Ito, 2018).

Many evacuees, especially younger ones, refuse to return even after decontamination is completed because of persisting high radiation in forests around houses and hot spots, health risk, destructed business and community infrastructure, established life in other regions, etc. Major reasons for slow progress are: delayed reconstruction, lengthy lands decontamination, existing hotspots, restricted mobility in evacuated areas, calls for more decontamination, difficulties in the safe disposal of contaminated soil and debris, population fears regarding radiation hazards, concern about the safety of intermediate nuclear waste storage facility, lack of job opportunities, destructed business, unrestored critical services and infrastructure, absence of communities consensus for certain projects, uncertainty for future developments, etc.

Insufficient decontamination of farmland and irrigation canals, decreased motivation among farmers, and local anxiety over rumours about produce are major reasons for the low resumption of farming in the evacuation zone. It has been difficult to farm efficiently (e.g. water control in paddies) since farmers were forbidden to stay permanently, there is uncertainty associated with marketing, and radioactive water runoff from mountains to reservoirs and paddy fields.

Food safety measures let Fukushima agri-food products become "safest in the world" but enormous public and private actions to increase safety and transparency have not to recover consumer trust. Demand for agri-food products from affected regions in Japan and internationally stay low due to lack of sufficient capabilities in the inspection system, inappropriate restrictions (initially covering all shipments in prefecture rather than contaminated localities), revealed rare incidences of contamination in commonly safe origins, low confidence in official "safety" limits and inspections, lack of good communication, harmful rumours ("Fu-hyo"), or unauthentic products (Bachev and Ito, 2018; MAFF, 2021). Recent data indicate that despite enormous public support the sales in the fishery and food processing industries have only recovered to $31.2 \%(70,7 \%$ in the construction industry) (FPG, December 2020). Demand for agri-food products has been "recovering" but wholesale prices are lower than national (Figure 1). That is a consequence of an increased number of inspections, reduction of radioactive contaminations, improving consumer confidence in inspection and safety, "forgetting" contamination issue by some part of the population, preferences to lower prices regardless of quality by some consumers, changing marketing strategies (not promoting/labelling products as "Fukushima origin"), increasing procurement by restaurants and processors, etc. All these have led to outmigration of the younger generation from Fukushima prefecture and low interests in most affected subsectors like agriculture, food processing, fisheries, etc.

There are challenges with the safety inspection system. Due to lack of personnel, expertise, high-precision equipment, the water, food, and soil tests are not always accurate (detecting single-digit according to new regulation), consistent and comprehensive. Food safety inspections are carried out at the distribution stage (output for shipment, export), and do not (completely) cover produces for farmers' markets, direct sales, food exchanges, and self-consumption. Capability for radiation safety control in Fukushima prefecture is high while in other prefectures strict tests are not carried out while contamination has "no administrative borders". Many private/collective testing equipment is not with high precision and samples are properly prepared (by inexperienced farmers). There are considerable discrepancies in measurements of radiation levels (air, food) done by different entities in the same location. Certain sold products are labelled as safe despite contamination and some tested agricultural products are further cooked or dried reaching higher radiation during consumption. Uptake of radioactive materials with food increases during the summer season (fresh vegetables/fruits consumed) and there are untested wild plants and home-produced food widely consumed by locals.

Agri-food inspections, regulations, and countermeasures are conducted in different agencies with "own" policies and not (well)coordinated procedures - Ministry of Agriculture, Forestry and Fisheries (soil contamination surveys and agri-food inspection), Ministry of 
Health, Labour and Welfare (food safety standards regulations), Ministry of Education, Culture, Sports, Science and Technology (monitoring air radiation), Ministry of Environment (decontamination and waste disposal), Consumer Affairs Agency (food safety training, Reconstruction Agency (restoration and decontamination). There are no common procedures, standards, and coordination between monitoring carried out at different levels and different government, professional, research, etc. organizations. Neither there is a common framework for centralizing and sharing all information and making it available to interested parties and the public.

Official "area-based" system for shipment restrictions harms many farmers producing safe commodities, instead of permit shipment by selected farmers is more appropriate. Extending random sampling tests of circulating produce (shipment level) with management/control at the production "planning" stage is superior. According to many, the biggest hurdle is the lack of a clear radiation risk standard that can be universally accepted since there are ongoing discussions among experts about "safety limits" and that confuses producers and consumers. Another challenge of the inspection system is the costs for local authorities, farmers, the food industry, etc. Fukushima prefectural government maintains several tested items, funding is depleting while the central government decreases screened items number. Much of the inspection costs of cooperatives, farmers, food processors, etc. are not compensated.

There are challenges with emerging new technologies and organizational modes - for high building and running costs, difficulties in cultivation technique, human development, food certification system, needs for stable marketing through integration, the requirement for entrepreneurship, collective actions, big investment, taking over by non-agrarian capital/entities, which are not available, well-accepted or legitimate. A negative outcome from restoration projects has been that farmland partitions expanded in Iwate, Miyagi, and Fukushima prefectures (MAFF, 2021).

Another challenge is a health risk for the population caused by radiation exposure. Thanks to timely measures (warnings, protection, evacuation, monitoring, decontamination, food inspections, treatment), radiation levels for the population have been well below the norms damaging health (WHO, 2013). Air dose rates around the country and within critical places in Fukushima prefecture have been higher than before the disaster but comparable with major cities in Japan and overseas (FPG, 2021). Surveys in most affected regions indicate that annual radiation intakes from foods are less than $1 \%$ of the maximum allowed and decreasing, while in the country as a whole is insignificant (MHLW, 2020).

Official "safe" radiation exposure levels were drastically increased from $1 \mathrm{mSv}$ to $20 \mathrm{mSv}$ per year in 2011. There have been debates and great concerns about health effects from cumulative exposure above and within the official limit. That worries are enforced by controversial opinions of experts, slow process of decontamination in some areas, the unresolved issue with safe disposal of contaminated debris, deficiency in food safety control, continuing radiation leakages in the nuclear plant, etc. Since FNA complaints and hospitalization have been increasing in Fukushima prefecture (Bachev and Ito, 2018). Nevertheless, the health effects of radiation release are "primarily psychological rather than physical" since many consumers and producers "lose peace of mind" having food with (lower than official safety limit but) radiation contamination. Long-life as an evacuee, lost property and employment caused many to develop physical or mental (stress, anxiety) problems, and "disaster-related deaths" reached several thousand. However, it is becoming increasingly difficult to identify relationships between health problems and deaths and FNA due to a long period.

TEPCO (operator of the nuclear power station) has paid trillions of yens in compensation related to FNA but still, there are thousands of claimants seeking or disputing compensations from TEPCO or authorities. Estimated compensation amount grows up constantly due to new governmental guidelines or as a result of court decisions for compensations. The number of false claims and swindling compensation funds for millions of yens has been also reported. Progress in compensation payments has been slow and uneven due to delays in TEPCO's review process; great paper works; lengthily negotiation; 
delays in payments; partial payments; disputing origin of damages; denying claims when production/distribution are restrained voluntarily; farmland, property, and discontinuation of business damage uncompensated; disagreements overcompensation "closing date; insufficient amount to restart farming/sustain consumption; inspection, administrative, radiation map preparation, etc. costs of organizations uncompensated; damages support unclearly specified in guidelines; negotiation asymmetry for farmers marketing through cooperatives; high lawyers costs; "safety tests" costs of farmers and consumer associations uncompensated; lack of clarity how certain claims be compensated; cash-flow difficulties and interest payments; uniform compensation "per ares" while differences in products, value-added, method (organic, conventional), etc.

Central and local governments have been spending tens of trillions of yens for reconstruction and revitalization actions (RA, 2021). There has been huge progress in these areas and numerous "good examples" but overall long-term effects of all this spending on the agro-food sector are difficult to access.

There is also uncertainty about full costs related to FNA due to expanding costs for decommissioning and counter adverse impacts. Decommissioning of nuclear reactors is at the beginning stage and there are many challenges related to lack of experiences, available technologies, uncertainties and risks, multiple failures, public concerns, lack of disposal site, impacts on populations and other industries, etc. In addition, there is a huge amount (16-22 mil.m3) of soil, leaves, mud, and other radioactive waste which has been stored in thousands of "temporary" storage sites across 13 prefectures. There is also a big amount of "designated waste" (143,689 tons) containing radioactive substances measuring more than $8000 \mathrm{~Bq} / \mathrm{kg}$. A temporary (30 years) storage facility for radioactive waste near the nuclear plant operates since 2017 while a site for final disposal of radioactive waste is not chosen because of the opposition of residents and industries in other prefectures. According to some experts undertaken large-scale decontamination creates new eco-problems: huge amounts of radioactive waste, removal of topsoil, damage to wildlife habitat and soil fertility, increased erosion on hillsides and forests, intrusion by people and machinery into every ecosystem, etc. Due to challenges with handling treated waters (accidental leakages, control release in the ocean, etc.) now to work not to generate "new" harmful rumours towards the Fukushima agriculture, forestry, and fisheries industry and tourism industry is high on the agenda (FPG, 2021).

There have been several new disasters in Japan (Typhoon Hagibis, Classical swine fever, ongoing Coronavirus epidemic, etc.) affecting additionally population, sectors, and food supply in the Fukushima accident regions and beyond. Besides the destruction of production (damages on crops, livestock, facilities, shortage of immigrant labour, etc.), they particularly badly enhanced the effects on demands of Fukushima agri-food products (closure of schools, restaurants, restriction on tourisms and countryside stays, cancelation of revitalization and traditional events, stagnation of acceptance of foreign technical interns, overstocking by households and businesses, decrease in exports, etc.). There have been emerging alternative modes of marketing like home and post-delivery, processing of milk as well as information campaign on preventing and safety measures, promoting domestically and locally grown foods consumption, new support measures, etc. Special attention is being put on developing disaster-resistant communities able to withstand intense and frequently occurring disasters by promoting disaster prevention measures, disaster mitigation, and building national land resilience as well as several initiatives towards securing a stable food supply including formulation of guidelines on business continuity for the entire food supply chain (MAFF, 2021). Ongoing Coronavirus crises have also had some negative impact on international cooperation on FNA with overseas partners due to the impossibility for onsite visits and investigations, and face-to-face meetings.

A "new" challenge for the government agencies, communities, educational, business and professional organisations, etc. is to make sure that lessons learned are not forgotten and to effectively inform and prepare individuals, farmers, agro-businesses, communities, and government bodies for multiple risk management. 


\section{Lessons from Japanese experiences}

Major lessons from FNA readiness, impacts, and recovery in the agri-food sector are following:

- $\quad$ The triple March 2011 disaster was a rare but high-impact event, which came as a "surprise" even for a country with frequent natural disasters and a well-developed disaster risk management system like Japan. It is necessary to "prepare for unexpected", and design, build and test a multi-hazard disaster risk management for specific conditions of each country, region, sector, etc. Appropriate measures and sufficient resources (funding, personnel, stockpiles, shelter cites, transportation means, etc.) have to be planned for effective prevention, early warning, mitigation, response, and post-disaster relief and recovery from big disasters and accidents. Besides state resources, it is important to mobilize huge private, community, NGOs, and international capabilities, expertise, and means since the large-scale public-private partnership are necessary to identify and designate public and private resources in case of big destruction, evacuation, etc.

- Risk assessment is to include diverse (health, dislocation, economic, behavioral, ecological, etc.) hazards and complementary (food, supply, natural, biological, etc.) chains, spin-offs, and multilateral effects of a likely (natural, manmade, multiple) disaster(s). Modern methods and technologies are to be widely employed (mass and social networks, computer simulation, satellite imaging, etc.) for effective communication, preparation of disaster maps, assessment of likely impacts, planning evacuation routes, relief needs, and recovery measures, secure debris, and waste management, etc. It is crucial to involve multidisciplinary and multi-stakeholders teams as well as wide participation of all stakeholders in all stages of risk management to guarantee a holistic approach, "full" information and transparency, adequate risk assessment, preferences and capabilities, and maximum efficiency and full implementation.

- $\quad$ Risk management system is to be discussed with all relevant organisations and stakeholders, and measures taken to educate and train individuals, organizations, and communities for complex disasters and all contingencies. Individual responsibilities are to be well-specified and effective mechanisms for coordination of actions of authorities, organizations, and groups at different levels put in place and tested to ensure efficiency (speed, lack of duplication, gaps) during an emergency. Individual and small-scale operators dominate in the agri-food sector of most countries, and their proper information, training, and involvement is critical. The latter is to embrace diverse agri-food and rural organizations, consumers, and population of each age group and gender, which all have no disaster management "culture", knowledge, training, and plans (particularly for large and multiple disasters). It is very important to develop risk information and management systems for entering supply chains and appropriately train and fund all related agents.

- It is necessary to modernize (specific, overall) formal institutional environment (property rights, regulations, safety standards, norms, etc.) according to the needs of contemporary disaster risk management. Particular attention is to be put on updating agrifood safety, labour, health, biodiversity, and animal welfare standards, and ensure adequate mechanisms, qualified agents, and technical instruments for effective implementation. The agri-food inspection system is to be improved by creating uniform inspection manuals and standards, enhancing coordination and avoiding duplication, establishing inspection across prefectural borders, and a management system extending random sampling tests of marketed produce with management at the production "planning" stage.

- It is important to set up mechanisms to improve the efficiency of public resource allocation, avoid mismanagement and misuse of resources, reduce individual agents' costs for complying with regulations, and using public relief, support, and dispute resolution (court) system. That would let efficient allocation of limited social resources according to agents' needs and preferences, intensify and speed up transactions, improve enforcement (rights, laws, standards) and conflict resolution, decrease corruption, and accelerate 
recovery and reconstruction. It is obligatory to involve all stakeholders in decision-making and control, increase transparency at all levels and stages of disaster planning, management, and reconstruction. In case of evacuation, it is essential to secure proper (police, voluntary group) protection of private and public properties from thefts and wild animal invasion in disaster zones. Special attention is to be given to enhance and increase communities and food chain agents' capability for effective risk management since they (rather than authority or independent organisations) have "full" knowledge and strong incentives to deal effectively with risky events.

- $\quad$ Different agents and elements of the agri-food chain are affected unlikely from a disaster and have dissimilar recovery and adaptation capability. Most farming assets (multiannual crops, irrigation facilities, buildings, brands, biodiversity, landscape) are interlinked with land, and if the land is damaged a rapid recovery (rebuilding, relocation, alternative supply, etc.) is very costly or impossible. Smaller-scale and highly specialized enterprises, small-member communities and organizations, visitors, and tourists are more vulnerable and less able to protect, bear consequences, and recover. All that requires differential public support (intervention, compensation, funding, assistance) to various types of agents to provide emergency relief, accelerate recovery and diminish negative consequences.

- $\quad$ There is a strong "regional" specificity (interdependency) of agrarian, food, and rural assets. If a part of assets/products is damaged or affected (destruction of critical transportation, communication, distribution, electricity, and water supply infrastructure; nuclear, chemical, pathogen, etc. contamination) all agents in respective region are affected (including undamaged lands, livestock, produce, services, households' entire livelihood). To minimize damages, it is important to properly identify (locate) risk and take prevention measures, recover rapidly critical infrastructure, strictly enforce quality (safety, authenticity, origin, etc.) of products, and adequately communicate them to producers, processors, distributors, consumers, and the international community.

- Establishing accessible cooperative, quasi-public or public agricultural (crop, livestock, machinery, building, life, health, etc.) insurance system, including assurance against big natural, nuclear, multiple, etc. disasters, is very important for rapid recovery of affected agents, (sub)sectors and regions. Modernization of outdated (often informal) lands, material, biological, and intellectual property registration, and valorisation system is important for effective post-disaster compensation, recovery, and reconstruction. That is particularly true for numerous subsistent and "semi-market" holdings dominating the agro-food sector worldwide usually suffering significantly from disasters (losing all possessions) but get no market valuation, insurance, and/or public support.

- Specific responses to 2011 disasters highlighted comparative advantages of traditional communities and non-governmental organizations, and less "efficient" but more resilient structures (small-operators, partnerships) and subsectors (like one-season crops, poultry, pig, processing, etc.). The important role of small-scale farm and food organizations, informal networks, and leadership has been proven immediately after FNA till now in rapid agri-food supply, securing food safety and transparency, effective (self)recovery, reconstruction, technological and organizational innovations, networking, and decentralized actions. These governing modes have to be included in the disaster management system, relevant actors properly trained and appropriate responsibilities assigned.

- Good management of information and communication is extremely important in emergency, recovery, and post-disaster reconstruction. FNA proves that any delay, partial release, or controversies of official information hamper effective (re)actions of agents, and adversely affected public trust and behavior (e.g. buying from disaster regions). Before, during, and after a disaster(s) all available (risk, monitoring, measured, projected, etc.) information from all reliable sources is to be immediately publicized in understandable by everyone form through all possible means (official and community channels, mobile phones, social media, etc.). It is essential to publish alternative (independent, private, scientific, international) information, including in foreign languages, which builds public 
trust and increases confidence. In Japan, it has been difficult to find all available information related to FNA in a timely and systematized way (updates, diverse aspects, unified measurement, time series, alternative sources), and in most spoken foreign languages, making many foreigners and local sceptical about accuracy.

- $\quad$ Big disaster provides extraordinary opportunity to discuss, introduce and implement fundamental changes in (agricultural, economic, regional, energy, disaster management, etc.) policies, improve disaster management and food security, modernize regulation and standards, relocate farms and houses, consolidate lands and operations, upgrade infrastructure, restructure production and farming organizations, introduce technological and business innovation, improve the natural environment, etc. All opportunities are to be effectively used by central and local authorities through policies, programs, measures, and adequate support given for innovative private and collective initiatives. Special precaution is to be used that public programs, projects, and interventions not to lead to backword "development" like in partitioning of farmlands in most affected by GEJA areas.

- Importance of international cooperation in all areas is proven in FNA responses and recovery through sharing information, knowledge, expertise, know-how, specialized equipment, etc. It is particularly crucial to share internationally advance Japanese experience through media, visits, studies, conferences, etc., and turn Fukushima into a disaster risk management hub for other regions and countries. Positive Japanese experiences are to be adapted (instead of copying) to specific institutional, cultural, natural environment and risks structure of each community, subsector, region, and country.

- $\quad$ It is essential to learn from past experiences and make sure that "lessons learned" are not forgotten. Impacts and factors of disaster, disaster management, and post-disaster reconstruction are to be continuously studied, knowledge communicated to the public, and "transferred" to the next generation. It is critical to prepare for multiple disasters and share "good" and "bad" experiences with disaster prevention, management, and recovery with other regions and countries, to prevent that from happening again in the future.

\section{Conclusions}

Ten years after FNA there are still several social, economic, health, food safety, technological, environmental, etc. challenges during reconstruction and revitalisation in the region and elsewhere. Agriculture, the food industry, and food consumption are among the worst hit by disaster areas. The Agri-food sector of Fukushima prefecture has been severely affected and there are significant adverse consequences to other regions and food chains nationwide. Many of these negative effects can hardly be expressed in quantitative terms.

Post-disaster recovery and reconstruction give opportunities to learn from and induced considerable policies and institutional modernization in agri-food and other (energy, security, etc.) sectors, improve disaster prevention and management, food safety information and inspection, technological and product innovation, jobs creation, and investment, farmlands consolidation and enhancement, infrastructural amelioration, organizational restructuring, etc.

This study is just a part of an ongoing attempt to assess disaster management readiness, FNA impacts, and summarize lessons for agri-food chains and beyond. Research is incomplete due to a "short" period after disaster, insufficient and controversial data, difficulties to adequately assess long-term implications, cross over with other recent and current disasters and crises. More in-depth multi and interdisciplinary studies are necessary to fully evaluate agri-food impacts and improve disaster risk management. 


\section{References}

1. Bachev, H. (2011) Governing of Agro-Ecosystem Services in Bulgaria, Research Topics in Agricultural and Applied Economics 3, 94-129.

2. Bachev, H. (2013) Risk management in the agri-food sector, Contemporary Economics, Volume 7, Issue 1, 45-62.

3. Bachev, H. (2013) Competitiveness of Bulgarian Farms in Conditions of EU CAP Implementation, Agricultural Research Updates 5, 1-42.

4. Bachev, H. (2013) New Institutional Economics Framework for Assessing and Improving Agrarian Organisations, Вісник Київського національного університету імені Тараса Шевченка, 7, 5-17.

5. Bachev, H. (2014) Socio-economic and environmental impacts of March 2011 earthquake, tsunami and Fukushima nuclear accident in Japan, Journal of Environmental Management and Tourism, 5, 127-222.

6. Bachev, H. (2015) An Approach to Assess Sustainability of Agricultural Farms, Turkish Economic Review 3 (1), 29-53.

7. Bachev H. (2019) Assessment of Preparedness and Agri-Food Impacts of Fukushima Nuclear Accident: Implications for Improvement of Disaster Risk Management, in Leif Inge Magnussen (Editor) Disaster, Diversity and Emergency Preparation, IOS Press.

8. Bachev, H. and F.Ito (2014) Implications of Fukushima Nuclear Disaster for Japanese Agri-food Chains, International Journal of Food and Agricultural Economics, 2, 95-120.

9. Bachev, H. and F. Ito (2018): Agricultural Impact of Great East Japan Earthquake, KSP.

10. Brasor P. and M.Tsubuku (2018) Tepco's compensation for $3 / 11$ victims made matters worse, National, April 13, 2018.

11. Csaki, C., C Forgács, D Milczarek, J Wilkin (2008) Regional Outcome: Central and Eastern Europe. Restructuring market relations in food and agriculture of Central and Eastern Europe - Impacts upon small farmers.

12. Daniels, J. (2012): Advances in Environmental Research, New York: Nova Science.

13. FAO/IAEA (2018) Nuclear Emergency Response for Food and Agriculture, FAO/IAEA.

14. FPG (2021) Station, Fukushima Prefectural Government.

15. Hamada, N. and H.Ogino (2013) Earthquake Food safety regulations: what we learned from Fukushima nuclear accident, Journal of Environmental Radioactivity, 111, 83-99.

16. JFC (2014) Findings on impact of earthquake on food industry, farm management and purchasing behavior of consumers, Japan Finance Corporation, Tokyo.

17. Johnson, R. (2011) Japan's 2011 Earthquake and Tsunami: Food and Agriculture Implications, Congressional Research Service, Washington DC.

18. Kunii, N., M. Fujimura, Y. Komasa, A. Kitamura, H.Sato, T. Takatsuji, M. Jimba and S. Kimura (2018) Knowledge and Awareness for Radiocesium Food Monitoring after Fukushima Nuclear Accident, Int. J. Environ. Res. Public Health, 15, 2289.

19. Koyama, R. (2013) Influence and Damage by Nuclear Disaster on Fukushima's Agriculture, Commercial Studies, 4, 15-25.

20. MAFF (2021) Annual report, Ministry of Agriculture, Forestry, Fisheries, Tokyo.

21. MECSST (2011) Land contamination, Ministry of Education, Culture, Sports, Science, Technology.

22. ME (2021) Environmental Remediation in Japan, Ministry of Environment, Tokyo.

23. MHLW (2020): Survey of Dietary Intake of Radionuclides, Ministry of Health, Labor, Welfare, Tokyo.

24. Monma, T. I.Goto, T.Hayashi, H.Tachiya, K.Ohsawa (2015) Agricultural and Forestry Reconstruction After Great East Japan Earthquake, Springer.

25. Nakanishi T. and K.Tanoi (2013) Agricultural Implications of Fukushima Nuclear Accident, Springer.

26. Nakanishi, T. (2018) Agricultural aspects of radiocontamination induced by Fukushima accident, Proc. Jpn. Acad., 94, 20-34.

27. NRA (2021) Monitoring info of environmental radioactivity, Nuclear Regulation Authority, Tokyo. 
28. Oka, T. (2012) Application of cost-benefit analysis to regulation of foodstuffs contaminated with radioactive substances, Japan J. Health Physics, 47, 181-188.

29. Osawa, M. and K. Ujiie (2016) Changes in consumer leafy vegetable consumption behavior after the nuclear accident, Food system research, Vol.23, 3, 213-218.

30. Sekizawa, J. (2013) Appropriate Risk Governance on Radionuclide Contamination in Food in Japan, Issues Learned from 3.11 Disaster, Society for Risk Analysis, 31-35.

31. RA (2021) Progress to date, Reconstruction Agency, Tokyo.

32. Takebayashi Y., M. Murakami, S. Nomura, (2020) The trajectories of local food avoidance after FDNPD, International Journal of Disaster Risk Reduction, 46, 101513.

33. Todo, Y., K. Nakajima, and P. Matous (2015) How Do Supply Chain Networks Affect Resilience of Firms to Natural Disasters? Journal of Regional Science, 55, 209-229.

34. Ujiie, K. (2012) Consumer's evaluation on radioactive contamination of agricultural products in Japan, Food Syst Res, 19, 142-155.

35. Watanabe N. (2013) Current State of Losses from Nuclear Accident and Support Measures by JA, Norinchikin Research Institute, Tokyo.

36. WHO (2013) Health risk assessment from nuclear accident after Great East Japan Earthquake, World Health Organization, Genève.

37. Башев X. (2009) Оценка на въздействието на ОСП на ЕС върху устойчивостта на животновъдните стопанства, Икономика и управление на селското стопанство, 1 , 8-18.

38. Башев X. (2011) Оценка на конкурентоспособността на земеделските кооперации, Икономика и управление на селското стопанство, 1, 22-30.

39. Башев X. (2011) Конкурентоспособностт на земеделските стопанства на физически лица, Икономика и управление на селското стопанство, 5, 55-65.

40. Башев X. (2012) Ефективност на икономическите организации и обществената интервенция в земеделието, Икономика и управление на селското стопанство, 3, 24-44.

41. Котева, Н. И Х. Башев (2010) Подход за оценка на конкурентоспособността на земеделските стопанства, Икономика и управление на селското стопанство, 1, 3243.

42. Котева, Н. И Х. Башев (2011) Изследване на конкурентоспособността на земеделските стопанства в България, Икономическа мисъл, бр 5, 34-638. 